\title{
Proton pump and plant cell elongation
}

\section{Anastasia Kirpichnikova, Tingzhuo Chen, Serafima Teplyakova, and Maria Shishova}

Department of Plant Physiology and Biochemistry, Faculty of Biology, Saint Petersburg State University, Universitetskaya nab., 7-9, Saint Petersburg, 199034, Russian Federation

Address correspondence and requests for materials to: Maria Shishova, mshishova@mail.ru

\begin{abstract}
Plant cell elongation growth is an integral process involved in different plant movements (tropisms); it provides the possibility to reach different resources of energy, water and nutrition and is therefore important for metabolism and development. Cell multiple enlargement along the longitudinal axis is commonly accepted to be under the control of the phytohormone auxin. One of the key enzymes involved in elongation is the plasma membrane $\mathrm{H}^{+}$-ATPase, which is known to acidify the cell wall. Investigation of the role of the proton pump at the plasma membrane was initiated by Prof. Vsevolod V. Polevoi and still is in progress in the group of Prof. Maria F. Shishova at the Department of Plant Physiology and Biochemistry, St. Petersburg State University. Different mechanisms of post-translation regulation of $\mathrm{H}^{+}$-pump activity are discussed in this review. We also suggest a possible scheme of elongation growth based on the shift in plant cell sensitivity to auxin and on its facility to elongate.
\end{abstract}

Keywords: $\mathrm{H}^{+}$-pump, plasma membrane, elongation growth, auxin, phosphorylation, exocytosis.

\section{Introduction}

The investigation of the auxin effect on plant cells was initiated by Professor Vsevolod Vladimirovich Polevoi in the 1960s at the Department of Plant Physiology and Biochemistry in St. Petersburg (Leningrad) State University. A collective of like-minded researchers from the Department and Laboratory of the Functional Activity of Membranes at the Biological Research Institute accumulated a huge amount of data proving the involvement of the plasma membrane (PM) $\mathrm{H}^{+}$-ATPase in auxin-induced elongation growth. The evidence nicely fit the acid growth theory (Cleland et al., 1971; Hager et al., 1971; Polevoi, 1986; Polevoi and Salamatova, 1977). Long-term investigation under Prof. V. Polevoi's supervision and in a number of other scientific groups did not succeed in showing a direct auxin effect on the PM H $\mathrm{H}^{+}$-ATPase. Accumulated data were combined by Prof. Polevoi in a scheme which presumed the involvement of different transduction pathways and second messengers like $\mathrm{Ca}^{2+}$ in intensification of proton pump activity (Polevoi et al., 1996; Fig. 1). Two possible mechanisms of the auxin action were proposed: 1 ) auxin directly activates $\mathrm{Ca}^{2+}$ influx in the cytosol. $\mathrm{Ca}^{2+}$ elevation initiates vesicle secretion but inhibits proton pump activity for a short time. Both phenomena trigger systems of $\mathrm{Ca}^{2+}$ and $\mathrm{pH}$ state, which will return conditions to the initial level. In parallel, the increase of protein synthesis is necessary to enhance the $\mathrm{H}^{+}$-ATPase activation required for hormone action and cell growth; 2) auxin induces $\mathrm{Ca}^{2+}$ cytosolic elevation due to the activation of phospholipase $\mathrm{C}$ and the phosphoinositide cycle; this is followed by the release of $\mathrm{Ca}^{2+}$ from the vacuole. The increase in $\mathrm{Ca}^{2+}$ concentration stimulates protein kinases and causes intensification of $\mathrm{H}^{+}$-ATPase activity at the plasma membrane (Polevoi et al., 1996). Both mechanisms supposed post-translation activation of the proton pump. 
Modern data on different mechanisms of plant cell $\mathrm{H}^{+}$-ATPase regulation will be presented in this review. The importance of the cell physiological status (stage of elongation growth) in the coordination of elongation growth is assumed.

\section{Regulation of plasma membrane $\mathrm{H}^{+}$-ATPase at post-translational level}

The plasma membrane proton pump belongs to $\mathrm{P}$ type ATPases - i.e. it is phosphorylated during the catalysis of the reaction of ATP degradation (EC 3.6.3.6). This enzyme is $\mathrm{Mg}^{2+}$-dependent and $\mathrm{K}^{+}$-stimulated. It plays an important bioenergetics and regulatory function in plant cell physiology (Polevoi, 1986; Gaxiola, Palmgren, and Schumacher, 2007). The structure and evolution of the PM proton pump are well documented (Pedersen et al., 2007, 2012). The protein consists of six transmembrane domains, two cytosolic loops and a long C-terminal domain (rev. in Morth et al., 2011). In Arabidopsis this $100-\mathrm{kDa}$ enzyme is encoded by a gene family consisting of 11 members, which can be divided into five subfamilies. Two forms, AHA1 and AHA2, are mainly expressed all over plant tissues (Baxter et al., 2003; Haruta et al., 2010).

The most common form of post-translational modifications of the $\mathrm{PM} \mathrm{H}^{+}$-ATPase is phosphorylation and dephosphorylation of the protein. The first evidence of phosphorylation site was obtained with spinach $\mathrm{PM} \mathrm{H}^{+}$ATPase (Olsson, Svennelid, Sommarin, and Larsson, 1998). This phosphorylation significantly modulates activity of the enzyme (Gaxiola, Palmgren, and Schumacher, 2007). Phosphorylation of the conservative amino acid residue (Thr) inside the autoinhibitory C-terminal domain is followed by interaction with 14-3-3 proteins from among well-known cytosolic regulators (rev. in Ferl, 2004). This binding initiates formation of a multisubunit complex consisting of six molecules of $\mathrm{H}^{+}$ATPase and six molecules of the 14-3-3 protein. Such aggregation increases the enzyme activity and is supposed to be a unique mechanism for P-type ATPases (Duby and Boutry, 2007). This aggregation is shown, for example, under the action of blue light (Ueno et al., 2005), and also under effect of osmotic (Babakov et al., 2000) and cold (Chelysheva et al., 1999) stressors. Moreover, this phosphorylation is fast and appears in a few minutes.

In vivo phosphorylation was detected for Thr947 residue in AHA2 Arabidopsis $\mathrm{PM} \mathrm{H}^{+}$-ATPase isoform (Nühse, Stensballe, Jensen, and Peck, 2003; Nühse, Bottrill, Jones, and Peck, 2007). The regulatory threonine residue is highly conserved in all known $\mathrm{H}^{+}$-ATPases, with the exception of the maize enzyme MHA1, in which threonine is replaced by proline. It was suggested that the activation of MHA1 occurs by another mechanism,

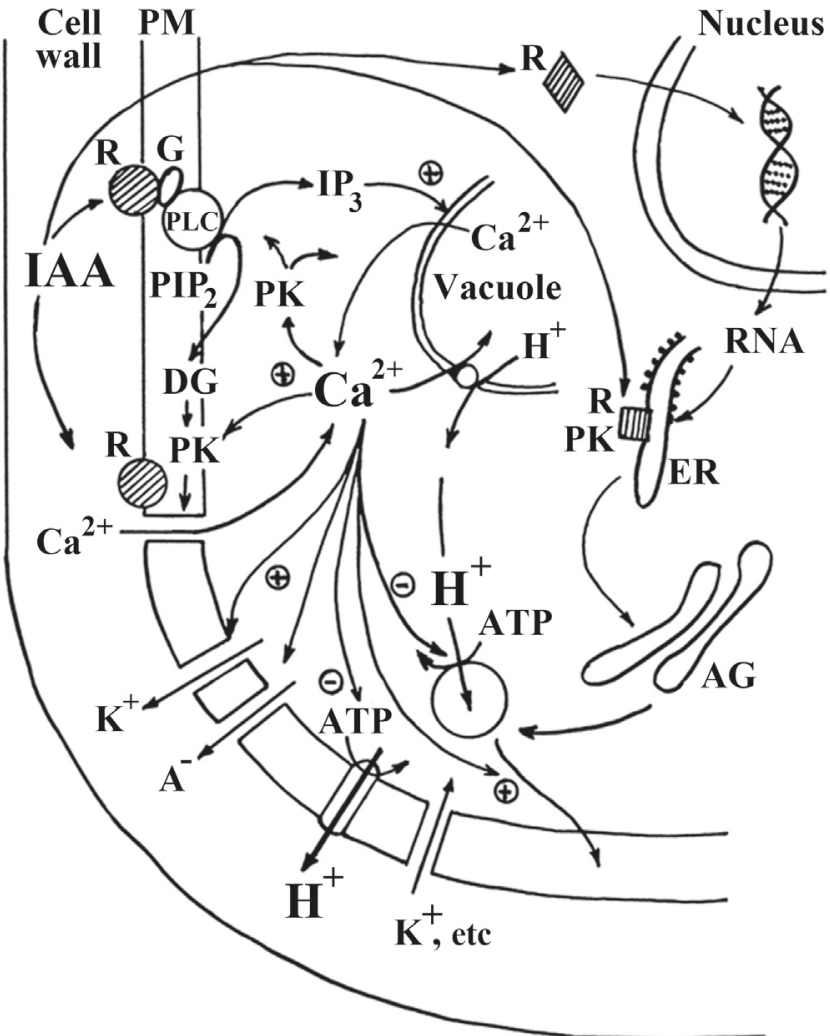

Fig. 1. Hypothetical scheme for the mechanism of auxin action. DG - diacylglycerol, G - G-proteins, IP $_{3}$ - inositol 1,4,5-triphisphate, $\mathrm{PIP}_{2}$ - phosphatidylinositol, 4,5-bisphosphate, $\mathrm{PK}$ - protein kinase, PLC - phospholipase C, PM - plasma membrane, $\mathrm{R}$ - receptor, AG - Golgi body, ER - endoplasmic reticulum (according to Polevoi et al., 1996).

or this isoform has another binding site for 14-3-3 proteins (Portillo, 2000). The protein kinase responsible for the phosphorylation of Thr947 $\mathrm{H}^{+}$-ATPase has not yet been identified (Gaxiola, Palmgren, and Schumacher, 2007; Falhof, Pedersen, Fuglsang, and Palmgren, 2016). Recently additional sites of phosphorylation have been revealed (Rudashevskaya et al., 2012; Haruta, Gray, and Sussman, 2015; Falhof, Pedersen, Fuglsang, and Palmgren, 2016). Among those sites were Ser-899, Ser904 and Ser-931 residues in AHA1 and AHA2 proteins of Arabidopsis. This indicates possible involvement of numerous protein kinases, which might regulate enzyme activity differently. For example, protein kinases PKS5, which belong to the family of $\mathrm{Ca}^{2+}$-dependent (CIPK11) kinases, can be classified as "inhibitory" protein kinases. In AHA2, phosphorylation by CIPK11 prevents binding to 14-3-3 proteins and thus inhibits the proton pump (Fuglsang et al., 2007). The reverse process of dephosphorylation of the proton pump by protein phosphatase 2A (PP2A) apparently occurs takes part. It has been shown that the regulatory subunit of PP2A binds to the C-terminus of $\mathrm{PM} \mathrm{H} \mathrm{H}^{+}$-ATPase (Fuglsang, Tulinius, Cui, and Palmgren, 2006). 
Besides phosphorylation/dephosphorylation and interaction with 14-3-3 proteins, several other mechanisms have been distinguished in recent years. Another protein that regulates the activity of the PM proton pump is PPI (proton pump interactor isoform 1). This protein interacts with the C-terminal domain of the plasmalemma $\mathrm{H}^{+}$-ATPase (Bonza et al., 2009). The PPI1 regulator was the first identified for Arabidopsis PM H${ }^{+}$-ATPase AHA1 isoform. It consists of 612 amino acid residues with high representation of polar and charged ones. PPI1 is not homologous to any of the proteins with a known function and, potentially, might be a representative of a new family of plant regulatory proteins. At least five Arabidopsis genes and EST sequences (expressed sequence tags) from different plant species encode proteins substantially similar to PPI1 (Morandini et al., 2002; Anzi et al., 2008). Intensive expression of genes encoding the PPI1 protein has been demonstrated in most plant organs - in the vascular tissues of roots and shoots, in meristematic tissues, in pollen, stigma of pestles, and pods (Anzi et al., 2008). The PPI1-binding site at the $\mathrm{C}$-terminus of the enzyme molecule has a different localization than the binding site of 14-3-3 proteins. Nevertheless, only a relatively small fraction of this protein is associated with the plasma membrane. The pool of PPI1 in the cell is bound to the membranes of the endoplasmic reticulum (Bonza et al., 2009). It is suggested that PPI1 can interact with newly synthesized PM $\mathrm{H}^{+}$-ATPase molecules, leading to a change in its activity. Another more likely suggestion is that PPI1 migrates to the plasma membrane, under effect of different factors, and binds to the $\mathrm{H}^{+}$-ATPase directly at the PM (Bonza et al., 2009). This regulation is involved in a number of physiological reactions; for example, PPI1 enhances $\mathrm{H}^{+}-$ ATPase activity under fusicoccin treatment (Morandini et al., 2002; Viotti, Luoni, Morandini, and De Michelis, 2005).

Another protein that is supposed to have a direct effect on the PM $\mathrm{H}^{+}$-ATPase is auxin-binding protein 57 (ABP57), which stimulates $\mathrm{H}^{+}$-ATPase in the presence of the hormone and thus elevates growth capacity (Kim, Kim, and Jung, 2000; Kim, Ming, Kim, and Jung, 2001). According to the concept of the three conformation states of ABP 57, a transition in-between state depends on auxin concentration. This mechanism might be of a great importance in revealing the auxin effect on the PM proton pump, although further confirmation of this hypothesis has not been received.

Along with protein-dependent post-translational regulation of the $\mathrm{PM} \mathrm{H}^{+}$-ATPase, some other factors could affect the activity of the enzyme. The low $\mathrm{pH}$ level of the cytoplasm and the depolarization of the membrane potential have a positive effect (Hager and Moser, 1985; Rubinstein and Stern, 1986). An increase in intracellular $\mathrm{Ca}^{2+}$ concentration may, on the contrary, inhibit
$\mathrm{H}^{+}$-ATPase (Brault et al., 2004). This mechanism may be mediated by PKS5 kinase (Fuglsang et al., 2007), since it specifically interacts with $\mathrm{SCaBP} 1 \mathrm{Ca}^{2+}$ binding protein and is considered a component of the $\mathrm{Ca}^{2+}$ signaling system.

Another set of data reveals modulation of the PM enzyme activity by the membrane lipids (Kasamo, 2003). PM H ${ }^{+}$-ATPase requires phospholipids for its activation. If membrane lipids are removed by detergents, the activity of membrane proteins, including $\mathrm{H}^{+}$-ATPase, is suppressed. The exogenous addition of membrane phospholipids restores activity of the enzyme. The role of glycerolipids and sterols in modulation of the proton pump activity has also been demonstrated (Kasamo, 2003). Changes in the lipid composition of the membrane modify its fluidity, which in turn causes alterations in the enzyme conformation and thus, its activity. Another supposition is that the presence of a certain lipid environment close to the $\mathrm{PM} \mathrm{H}^{+}$-ATPase might affect the process of enzyme oligomerization through interaction with 14-3-3 proteins (Morales-Cedillo et al., 2015).

Taken together, data indicate complicity of the pathways involved in the regulation of the plasma membrane proton pump, although phosphorylation is assumed to be preferential.

\section{Plant hormones and growth regulators in modulation of PM proton pump activity}

Since the early 2000s, data on the enzyme hormone-dependent C-terminal domain phosphorylation has been accumulating (Palmgren, 2001; Takahashi, Hayashi, and Kinoshita, 2012; Chen, Hao, and Cao, 2014). It was shown that gibberellic acid enhances the phosphorylation of Thr-947, and cytokinin, on the contrary, reduces this process (Chen, Hao, and Cao, 2014). The binding of brassinosteroids to the BRI1 receptor resulted in rapid hyperpolarization (Caesar et al., 2011). Detailed analysis of the event is still in progress, but some data indicate the possibility of direct interaction of the receptor kinase BRI1 with AHA1. In contrast, abscisic acid (ABA), known to inhibit elongation, dramatically reduces the level of $\mathrm{H}^{+}$-ATPase phosphorylation after addition to guard cells (Hayashi, Inoue, Takahashi, Kinoshita, 2011; Chen, Hao, Cao, 2014). Similarly, in hypocotyls ABA decreases phosphorylation of Thr-947, depending on ABI1 phosphatase (ABA signaling proteins phosphatases 2C, Hayashi, Takahashi, Inoue, and Kinoshita, 2014). In roots, $\mathrm{ABA}$ inhibits proton transport by $\mathrm{H}^{+}$-ATPase. This inhibition is absent when the hormone perception is disordered or when phosphatase activity is blocked due to overexpression of HAB1 (Hayashi, Takahashi, Inoue, and Kinoshita, 2014; Planes et al., 2015). Fusicoccin is a fungal toxin of Fusicoccum amygdali that might be taken as an example of complicity of PM proton pump 
regulation. An incubation of $\mathrm{H}^{+}$-ATPase with fusicoccin triggers an increase in the phosphorylation level of the $\mathrm{Thr}$ as a result of the corresponding unknown kinase activity. The amount of endogenous 14-3-3 proteins bound to $\mathrm{H}^{+}$-ATPase is proportional to the level of phosphorylation (Kinoshita and Shimazaki, 2001). However, the presence of fusicoccin prevents dephosphorylation of $\mathrm{H}^{+}$-ATPase C-terminus by alkaline phosphatase and thus continuously activates the $\mathrm{PM} \mathrm{H}^{+}$-ATPase.

\section{Auxin as a regulator of PM proton pump activity}

Very serious attention was directed to the auxin effect on $\mathrm{H}^{+}$-ATPase. It was shown that the hormone initiates rapid phosphorylation leading to the activation of the enzyme, but does not change the amount of enzyme in the plasma membrane. However, some facts indicated that the well-studied signal cascade involving TIR1/ AFB receptors is possibly not involved in this process (Schenck, Christian, Jones, and Lüthen, 2010; Takahashi, Hayashi, and Kinoshita, 2012). The main reasons were the maintenance of auxin-induced elongation even in the quadruple tir1/afb mutant and the maintenance of phosphorylation of AHA, Arabidopsis $\mathrm{H}^{+}$-pump, in the double tir1-1afb2-3 mutant.

Nonetheless, a possible means of regulation of the PM proton pump by auxin was recently linked to the family of auxin-induced SMALL AUXIN UP-RNA (SAURs). Genes of this family, along with the representatives of AUX/IAAs and GH3s gene families, have long been known to be rapidly activated after auxin addition (Abel, Oeller, and Theologis, 1994; Hagen and Gilfoy, 2002). The number of SAURs varied significantly among plants, from 18 SAURs in mosses to 81 SAURs in Arabidopsis and even 134 SAURs in potato (see Ren and Gray, 2015 for a review). More than 674 SAUR genes have been identified in different plant species, but only a few of them have been functionally characterized ( $\mathrm{Li}$ et al., 2017). SAUR genes encode small proteins that are unique to plants, contain a conservative 60 amino acid domain but have no obvious characterized biochemical function. The predicted molecular weights of Arabidopsis SAUR proteins range from 9.3 to $21.4 \mathrm{kDa}$. Several SAUR proteins have been shown to be highly unstable. It was reported that maize SAUR2 (ZmSAUR2) protein had a half-life of about seven min, and its synthesis is specific to elongating tissues (Knauss, Rohrmeier, and Lehle, 2003). Arabidopsis SAUR19 and SAUR63 were also revealed to be unstable; their degradation involved the ubiquitin-26S proteasome pathway (Spartz et al., 2012). Both Arabidopsis SAUR19 and SAUR63 were found to be positive regulators of cell elongation in the hypocotyl (Chae et al., 2012; Spartz et al., 2012). The mechanism of SAURs action is supposed to be within the frame of the acid growth theory via stimulation of the $\mathrm{PM} \mathrm{H}^{+}$-pump. SAUR19 is known to interact with representatives of the PP2C. D family of protein phosphatases (Spartz et al., 2014). This binding prevents PP2C. D interaction with the proton pump and thus eliminates dephosphorylation and causes further inhibition (Ren and Gray, 2015; Fendrych, Leung, and Friml, 2016). This model assumes the role of auxin, which would trigger the whole cascade. Elegant experiments with elongating Arabidopsis hypocotyls revealed that auxin addition, nuclear auxin signaling, apoplast acidification and growth occur with a similar lag phase of approximately $20 \mathrm{~min}$ (Fendrych, Leung, and Frimi, 2016). Moreover, these results proved auxin-induced $\mathrm{H}^{+}$-ATPase-dependent elongation through TIR1/AFB perception and AUX/IAA transduction. Such an easy and logical pathway from the hormone to the key enzyme had been awaited for decades. Recently this pathway was revealed for Arabidopsis hypocotyl cells (Fendrych, Leung, and Frimi, 2016).

Nevertheless, application of auxin is followed by fast (minutes) membrane hyperpolarization, inhibited by vanadate, a specific inhibitor of $\mathrm{PM} \mathrm{H}^{+}$-ATPase; this indicates faster auxin-induced modulation of the PM enzyme. Taken together with the limited growth response to auxin in the tir1-1afb2-3 mutant, it leads to the question: does any other mechanism exist? Among rapid auxin-dependent reactions, the elevation of $\mathrm{Ca}^{2+}$ concentration in the cytosol, as well as acidification, have been known since the 1980s (Felle, 1988; Felle, Brummer, Bertl, and Parish, 1986; Felle, Peters, and Palme, 1991). This phenomenon has been estimated for different plant cells with different approaches (Gehring, Irving, and Parish, 1990; Irving, Gehring, and Parish, 1992; Shishova and Lindberg, 1999, 2004; Shishova et al., 1998; Shishova, Lindberg, and Polevoi, 1999; Monshausen et al., 2011; see for review Vanneste and Friml, 2013). The most debated question was the priority of acidification and $\left[\mathrm{Ca}^{2+}\right]_{\text {cyt }}$ increase. According to the set of experiments, acidification could be obtained with a lag period of about $80-100 \mathrm{~s}$. However, the shift in $\left[\mathrm{Ca}^{2+}\right]$ cyt concentration was distinguishable within the first $20 \mathrm{~s}$, suggesting it to be the primary transduction event. Millimolar extracellular $\mathrm{Ca}^{2+}$ concentration was important for auxin-induced reactions, including acidification (Ayling and Clarkson, 1994; Shishova and Lindberg, 1999; 2004). The internal pool of $\mathrm{Ca}^{2+}$ also was shown to be important, but the absence of extracellular calcium at the proper concentration led to delay in the auxin-induced elevation of its cytosolic concentration (Shishova and Lindberg, 2004). Cytosol acidification started with A23187 $\mathrm{Ca}^{2+}$ ionophore, and this effect was blocked by vanadate, which revealed the role of $\mathrm{H}^{+}$-ATPase in $\mathrm{Ca}^{2+}$ dependent $\mathrm{pH}$ decrease (Shishova and Lindberg, 2004). Moreover, $\left[\mathrm{Ca}^{2+}\right]_{\text {cyt }}$ elevation is not only the one primary rapid reaction. Its amplitude depends on the sensitivity 


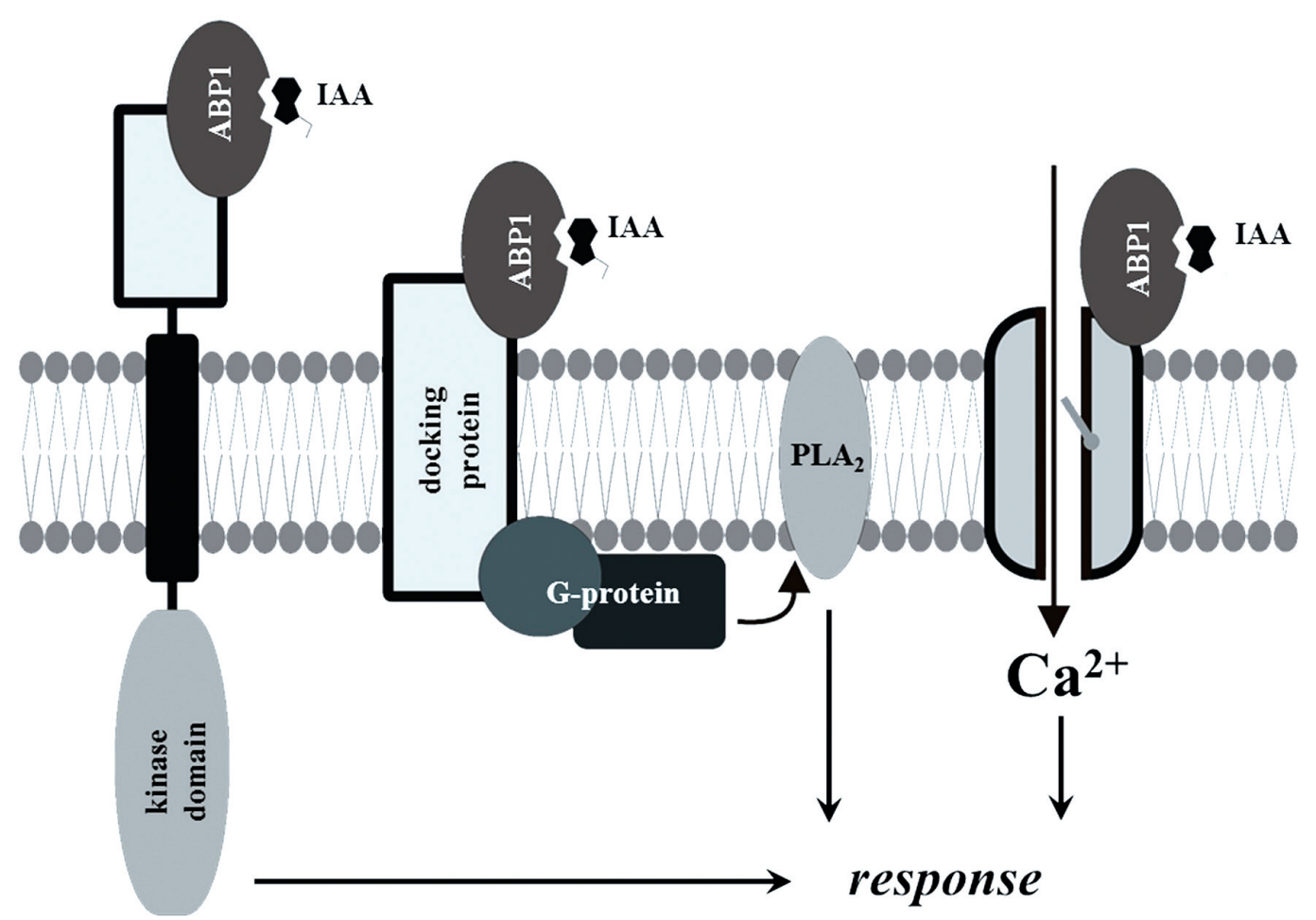

Fig. 2. Different models of the auxin receptor at the plasma membrane. a) receptor associated kinase; b) receptor, coupled with G-proteins; c) receptor, linked to $\mathrm{Ca}^{2+}$-ion channel. All the models assumed ABP1 as external domain of the receptor.

of plant cell affected by auxin (Shishova, Yemelyanov, Rudashevskaya, and Polevoi, 2007; Kirpichnikova, Rudashevskaya, Yemelyanov, and Shishova, 2014). Cereal coleoptiles are known to be very sensitive to auxin, and most cell populations respond to the hormone by elongation. The intensity of this auxin-dependent elongation slows down with the age of seedling. Thus, it might be assumed that with age, cells lose their facility to respond due to changes in the coleoptile physiological state. The same trend was estimated for $\left[\mathrm{Ca}^{2+}\right]_{c y t}$ elevation. Potoplasts obtained from cells of the youngest maize coleoptiles reacted to auxin by much stronger $\mathrm{Ca}^{2+}$ elevation blocked by $\mathrm{La}^{3+}$ and EGTA. Similarly, auxin initiated $\mathrm{Ca}^{2+}$ transport in coleoptile PM vesicles, and the intensity of calcium flux was extremely dependent on maize seedling age (Kirpichnikova, Rudashevskaya, Yemelyanov, and Shishova, 2014). According to the presented data, this $\mathrm{Ca}^{2+}$ membrane permeability might be modulated by auxin binding protein 1 (ABP1). This protein has a very intriguing history. For quite a long period, beginning in the 1980s, it was thought to be a part of the auxin receptor at the plasma membrane (see for reviews: Shishova and Lindberg, 2010; Grones and Friml, 2015). This is a $22-\mathrm{kDa}$ protein highly conservative over plant species, with $98 \%$ representation in the endoplasmic reticulum and minor (2\%) anchoring to the plasma membrane. Nevertheless, capacity to bind auxin was shown to be higher at cell wall acidic $\mathrm{pH}$ but not inside the ER (Tian, Dieter, and Jones, 1995). According to the model, ABP1 might couple a transmembrane (docking) protein (Klambt, 1990; Barbier-Brygoo et al., 1991) and via conformational change, which masks the KDEL tag, is secreted to the cell surface (Jones and Herman, 1993). The nature of the docking protein, as well as the biological function of ABP1, are still under discussion. Figure 2 represents three suggested schemes. According to the first hypothesis, the docking protein is a protein kinase (Barbier-Brygoo, 1995); the second one suggested involvement of a G-protein complex (MacDonald, 1997); and the third one predicted close interaction of auxin perception with the $\mathrm{Ca}^{2+}$-channel (Shishova et al., 1999).

Recently, a second round of ABP1 investigations started. It resulted in the conclusion that the significance of the ABP1 pathway was exaggerated because abp 1 knockout mutants did not reveal the proper auxindefective phenotype (Grones and Friml, 2015; Gao et al., 2015; Michalko, Dravecka, Bollenbach, and Friml, 2015; Michalko, Glanc, Perrot-Rechenmann, and Frimi, 2016). The absence of ABP1 in Arabidopsis did not change auxin-induced elongation. It could be the end point in the ABP1 story, but still a number of experiments have provided evidence of its role in growth regulation and even modulation of cell sensitivity to auxin. According to electrophysiological tests (hyperpolarization), maize ABP1 addition to tobacco leaf protoplasts elevated auxin sensitivity 100 - to 1000 -fold, whereas antibodies against 
ABP1 induced the opposite effect (Barbier-Brygoo et al., 1989; Barbier-Brygoo, 1995). A similar effect of the protein and antibodies against it were shown in other experiments - membrane potential detected with the whole cell patch-clamp technique (Ruck et al., 1993), auxin-specific protoplast swelling (Christian et al., 2006) and auxin-dependent PM permeability for $\mathrm{Ca}^{2+}$ (Kirpichnikova, Rudashevskaya, Yemelyanov, and Shishova, 2014). It was assumed that $A B P 1$ might increase the number of active perception units at the plasma membrane and thus should elevate protoplast sensitivity (Barbier-Brygoo, 1995). Interestingly, the highest level of ABP1 was closely correlated with maximum leaf cell expansion and with the lowest free auxin concentration, while the most intensive cell division corresponded with higher auxin levels but lower ABP1 content (Chen et al., 2001).

All the accumulated data did not answer the most intriguing question of how ABP1 contributes to elongation intensity and what could be a mechanism of auxin signal transfer from ABP1 to the PM proton pump. It might be suggested that auxin addition triggers permeability of the PM to calcium ions and involvement of $\mathrm{Ca}^{2+}$ signaling in auxin transduction. The increase in $\left[\mathrm{Ca}^{2+}\right]_{\text {cyt }}$ might activate different groups of kinases, with assistance of $\mathrm{Ca}^{2+}$ binding proteins phosphorylating $\mathrm{PM}$ $\mathrm{H}^{+}$-ATPase. But this effect could have a short negative effect on proton pump activity and cause rapid auxininduced cytosolic acidification and further activation of $\mathrm{H}^{+}$-ATPase (Felle, 2001).

Another well-known $\mathrm{Ca}^{2+}$-dependent process is vesicle secretion. In animal cells $\mathrm{Ca}^{2+}$ is thought to be a key regulator of exocytosis intensity and is considered to be more sensitive to cytosolic $\left[\mathrm{Ca}^{2+}\right]_{\text {cyt }}$ concentration in comparison to cereal coleoptile cells. Hence, the suggested phenomenon might indicate common mechanisms of signaling. Elevation of $\left[\mathrm{Ca}^{2+}\right]_{c y t}$ induced by auxin is shown to be in the range of about $100 \mathrm{nM}$ (Felle, 1988; Shishova and Lindberg, 2004). This is enough to activate the secretory system within 10-20 s after the increase in $\mathrm{Ca}^{2+}$ concentration (Sutter, Homann, and Thiel, 2000). The elongation process is accompanied by a fast increase in the cell surface and supported by the building of a new cell wall, which is strongly dependent on vesical secretion from the Golgi apparatus. Intensive exocytosis was shown for different cell types and found to be very sensitive to $\left[\mathrm{Ca}^{2+}\right]_{\text {cyt }}$ concentration (see for review: Battey, James, Greenland, and Brownlee, 1999). The process of exocytosis is well documented for pollen tubes and different secretory cells, and it has been shown to be important for elongating cells. Different mechanisms for vesicle membrane fusion have been suggested: SNAREs, Rop GTPase, and proteins with $\mathrm{Ca}^{2+}$-dependent phospholipid binding domain. At the pre-elongation stage, when growth has just been initiated, the in- tensity of vesicle secretion is minimal. After elongation starts, plasma membrane and tonoplast enlargement are supported by the vesicle path from the Golgi apparatus to the cell surface and vacuole. At the third stage, cell enlargement stops, but construction of a new cell wall depends on exocytosis. To prevent further enlargement of the cell PM vesicle, transport towards the PM might be compensated by endocytosis directed to the vacuole (Fig. 3). Thus, the balance between endo- and exocytosis might be determined by the stage of development (has the cell already passed elongation?), sensitivity to auxin (old cells respond differently to auxin), intensity of lighting (de-etiolation at dim/bright light transition), etc. Analysis of electronic micrographs of oat coleoptile cells reveals a $\sim 12 \%$ difference in the number of vesicles (Quaite, Parker, and Steer, 1983). The vesicle pool correlated with changes in growth capacity of the tested cells, and was bigger in cells which had started elongation. This nicely corroborated with the scheme in Figure 3. The importance of exocytosis for the mechanism of auxin action provides support to the earlier suggestion about a hormone-induced increase in the number of $\mathrm{H}^{+}$-ATPases in the plasma membrane via vesicle secretion (Hager et al., 1991). The intensity of $\mathrm{H}^{+}$-ATPase units/proteins increases within the plasma membrane and, thus, increasing enzyme activity would reflect the size of vesicle pools and the amplitude of auxin-induced $\mathrm{Ca}^{2+}$ elevation, which in turn depends on the cell stage of development. Recently, ROP GTPase signaling was suggested to be linked to ABP1 (Xu et al., 2011; Murphy and Peer, 2012), but the mechanism is still unknown. $\mathrm{ABP} 1$ increases cell sensitivity to auxin and triggers the PM permeability to $\mathrm{Ca}^{2+}$ (Kirpichnikova, Rudashevskaya, Yemelyanov, and Shishova, 2014). At the stage of elongation growth, ABP1 would affect cytosolic $\mathrm{Ca}^{2+}$ increase and activate exocytosis followed by $\mathrm{H}^{+}$-pump activation probably due to the increase in $\mathrm{H}^{+}$-ATPase units. Data obtained with electron microscopy reveals that about $60 \%$ of vesicles delivered to the plasma membrane are recycled (Phillips, Preshaw, and Steer, 1988). Endocytosis intensity was shown to depend on ROP GTPase (Yalovsky, Bloch, Sorek, and Kost, 2008) and on $\left[\mathrm{Ca}^{2+}\right]_{\text {cyt }}$ concentration (Hwang, Gu, Lee, and Yang, 2005). Plant cell endocytosis was found to be closely related to polarity. ABP1/ROP-dependent recycling provides redistribution of PINs proteins and thus leads to a redirection of auxin flow.

Based on the initial scheme of Prof. V. Polevoi, data obtained at the Department of Plant Physiology and Biochemistry, with incorporation of recently published results from other laboratories, the following scheme could be proposed (Fig. 4):

Auxin perception through the SCF ${ }^{\mathrm{TIR} 1 / \mathrm{AFB}}$ complex activates an unknown kinase responsible for phosphorylation of conservative Thr residue, further binding to 


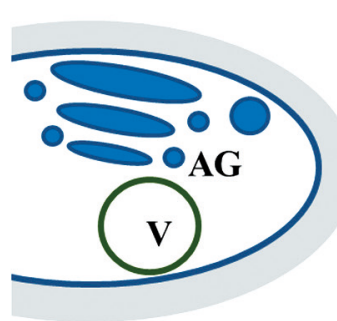

Pre-elongation stage (initiation of growth)

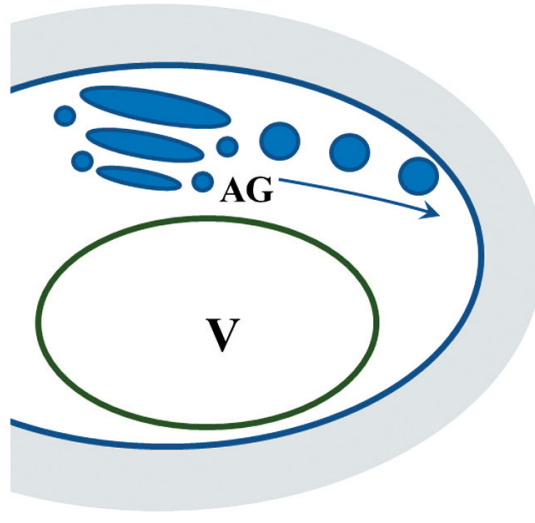

Elongation stage (active PM and vacuole growth)

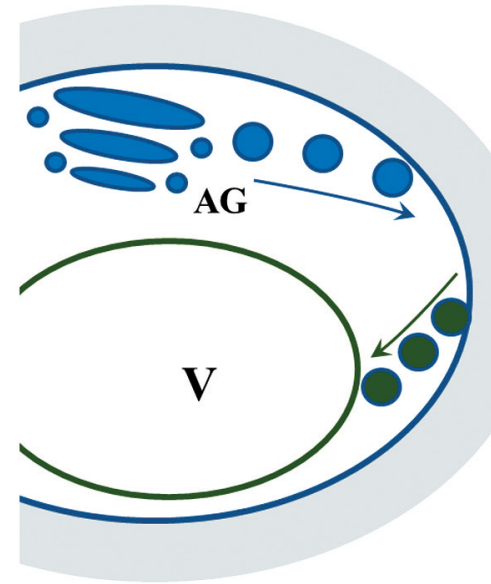

End of elongation stage (stabilization of PM and vacuole growth)
AG - Golgi apparatus
V - vacuole
Exocytosis vesicles
Endocytosis vesicles

Fig. 3. The role of exocytosis and endocytosis in plant cell membranes enlargement (according to Battly et al., 1999; Kirpichnikova et al., 2014).
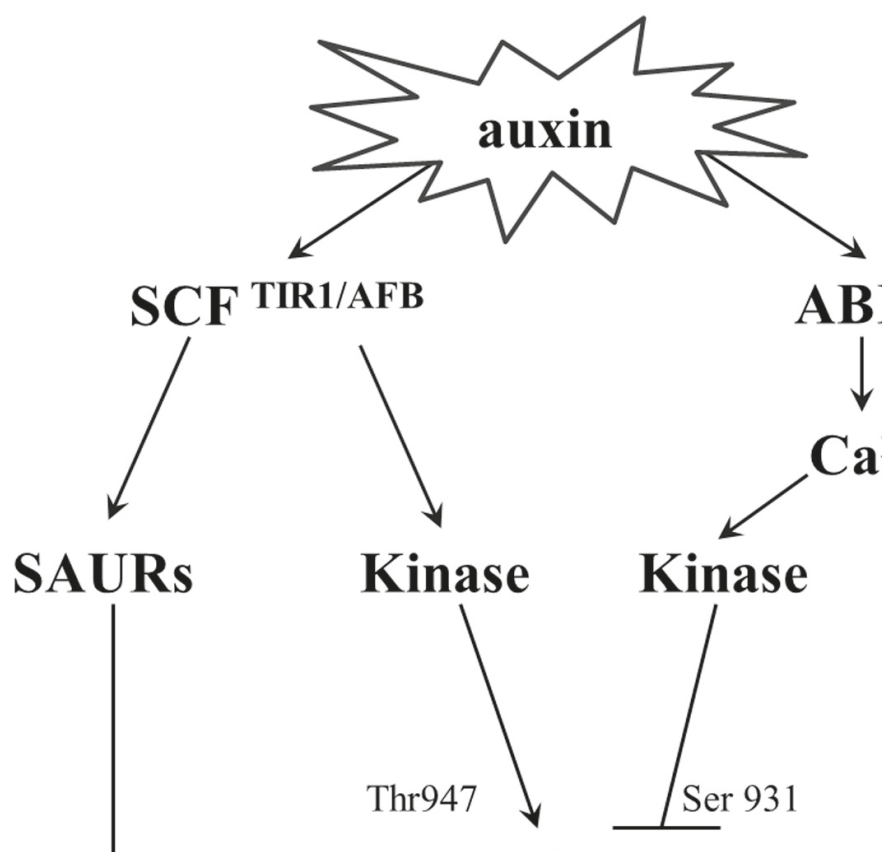

ABP1
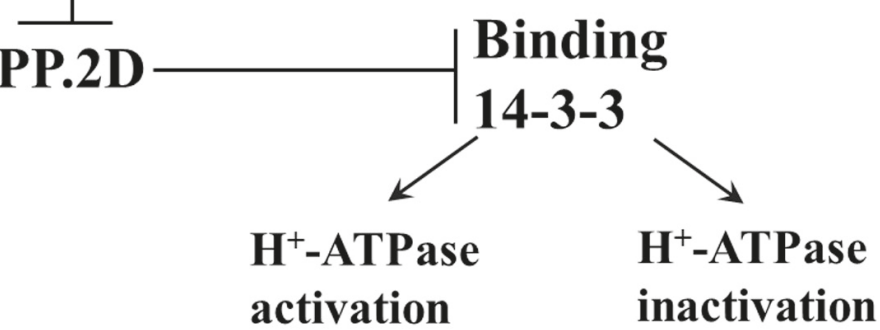

Increase of

$\mathrm{H}^{+}$-ATPase in PM

Fig. 4. The integrative scheme of the auxin activation of the plasma membrane proton pump. 
14-3-3 proteins, formation of a multimeric complex and the activation of $\mathrm{PM} \mathrm{H} \mathrm{H}^{+}$-ATPase. Dephosphrylation of Thr by phosphatases would alternatively block binding with 14-3-3 proteins and return the pump to the initial level of activity. Through the same perception mechanism, auxin activates expression of SAUR genes. Appearing SAUR proteins (like SAUR 19 and SAUR 63) block PP2C-D phosphatases and prevent dephosphorylation of conservative Thr947 of $\mathrm{H}^{+}$-ATPase. This results in prolonged activation of the PM proton pump and further elongation growth.

Another scenario might be suggested in the case of auxin perception through ABP1. Within $20 \mathrm{sec}$, it increases permeability of the PM to $\mathrm{Ca}^{2+}$ ions and results in fast elevation of calcium concentration in the cytosol. Transduction of the auxin signal with components of the $\mathrm{Ca}^{2+}$-signaling system includes $\mathrm{Ca}^{2+}$-binding proteins and activation of protein kinases, followed by phosphorylation of other amino acids residues (Ser931, etc.); this prevents binding of 14-3-3 proteins and activation of the $\mathrm{PM} \mathrm{H} \mathrm{H}^{+}$-pump by the post-translation mechanism. However, the event could have a positive role because short-time blockage of the proton pump results in cytosol acidification and could have a further stimulating effect on $\mathrm{H}^{+}$-ATPase when $\mathrm{Ca}^{2+}$ concentration drops down. Nevertheless, $\mathrm{Ca}^{2+}$ increase in the cytosol activates vesicle secretion, the direction of which depends on the cell development stage.

This suggested scheme combines quite a number of auxin effects on the activation of the plasma membrane of $\mathrm{H}^{+}$-pump. It still lacks the data that could finally indicate whether it depends on cell type, age and its sensitivity to auxin. Further investigations are required and expected.

\section{References}

Abel, S., Oeller, P. W., and Theologis, A. 1994. Early auxin-induced genes encode short-lived nuclear proteins. Proceedings of the National Academy of Sciences of the USA 91(1):326-330. https://doi.org/10.1073/pnas.91.1.326

Anzi, C., Pelucchi, P., Vazzola, V., Murgia, I., Gomarasca, S., Beretta Piccoli, M., and Morandini, P. 2008. The proton pump interactor (Ppi) gene family of Arabidopsis thaliana: expression pattern of Ppi1 and characterization of knockout mutants for Ppi1 and 2. Plant Biology 10(2):237249. https://doi.org/10.1111/j.1438-8677.2007.00022.x

Ayling, S. M. and Clarkson, D. T. 1996. The cytoplasmic streaming response of tomato root hairs to auxin: The role of calcium. Australian Journal of Plant Physiology 23(6):699708. https://doi.org/10.1071/PP9960699

Babakov, A.V., Chelysheva, V.V., Klychnikov, O. I., Zorinyanz, S. E., Trofimova, M.S., and De Boer, A. H. 2000. Involvement of 14-3-3 proteins in the osmotic regulation of $\mathrm{H}^{+}$-ATPase in plant plasma membranes. Planta 211(3):446-448. https://doi.org/10.1007/s004250000347

Barbier-Brygoo, H. 1995. Tracking auxin receptors using functional approaches. Critical Reviews in PlantSciences 14(1):125. https://doi.org/10.1080/07352689509701920
Barbier-Brygoo, H., Ephritikhine, G., Klämbt, D., Ghislain, M. and Guern, J. 1989. Functional evidence for an auxin receptor at the plasmalemma of tobacco mesophyll protoplasts. Proceedings of the National Academy of Sciences of the USA 86(3):891-895. https://doi.org/10.1073/ pnas.86.3.891

Barbier-Brygoo, H., Ephritikhine, G., Klämbt, D., Maurel, C., Palme, K., Schell, J., and Guern, J. 1991. Perception of the auxin signal at the plasma membrane of tobacco mesophyll protoplasts. Plant Journal 1(1):83-93. https://doi. org/10.1111/j.1365-313X.1991.00083.x

Battey, N. H., James, N. C., Greenland, A. J., and Brownlee C. 1999. Exocytosis and endocytosis. Plant Cell 11(4):643659. https://doi.org/10.1105/tpc.11.4.643

Baxter, I., Tchieu, J., Sussman, M. R., Boutry, M., Palmgren, M. G., Gribskov, M., Harper, J. F., and Axelsen, K. B. 2003. Genomic comparison of P-type ATPase ion pumps in Arabidopsis and rice. Plant Physiology 132(2):618-628. https:// doi.org/10.1104/pp.103.021923

Bonza, M. C., Fusca, T., Homann, U., Thiel, G., and De Michelis, M. I. 2009. Intracellular localisation of PPI1 (proton pump interactor, isoform 1), a regulatory protein of the plasma membrane $\mathrm{H}^{+}$-ATPase of Arabidopsis thaliana. Plant Biology 11(6):869-877. https://doi. org/10.1111/j.1438-8677.2008.00181.x

Brault, M., Amiar, Z., Pennarun, A. M., Monestiez, M., Zhang, Z., Cornel, D., and Rona, J. P. 2004. Plasma membrane depolarization induced by abscisic acid in Arabidopsis suspension cells involves reduction of proton pumping in addition to anion channel activation, which are both $\mathrm{Ca}^{2+}$ dependent. Plant Physiology 135(1):231-243. https://doi. org/10.1104/pp.104.039255

Caesar, K., Elgass, K., Chen, Z., Huppenberger, P., Witthöft, J., Schleifenbaum, F., and Harter, K. 2011. A fast brassinolide-regulated response pathway in the plasma membrane of Arabidopsis thaliana. Plant Journal 66(3):528540. https://doi.org/10.1111/j.1365-313X.2011.04510.x

Chae, K., Isaacs, C. G., Reeves, P. H., Maloney, G. S., Muday, G. K., Nagpal, P., and Reed, J.W. 2012. Arabidopsis SMALL AUXIN UP RNA63 promotes hypocotyl and stamen filament elongation. Plant Journal 71(4):684-697. https://doi.org/10.1111/j.1365-313X.2012.05024.x

Chelysheva, V.V., Smolenskaya, I. N., Trofimova, M. C., Babakov, A.V., and Muromtsev, G.S. 1999. Role of the 14-3-3 proteins in the regulation of $\mathrm{H}^{+}$-ATPase activity in the plasma membrane of suspension-cultured sugar beet cells under cold stress. FEBS Letters 456(1):22-26. https://doi.org/10.1016/S0014-5793(99)00923-0

Chen, J.-G., Shimomura S., Sitbon, F., Sandberg, G., and Jones, A. M. 2001. The role of auxin-binding protein 1 in the expansion of tobacco leaf cells. Plant Journal 28(6):607-617. https://doi.org/10.1046/j.1365313x.2001.01152.x

Chen, Y., Hao, X., and Cao, J. 2014. Small auxin upregulated RNA $(S A U R)$ gene family in maize: identification, evolution, and its phylogenetic comparison with Arabidopsis, rice, and sorghum. Journal of Integrative Plant Biology 56(2):133-150. https://doi.org/10.1111/jipb.12127

Christian, M., Steffens, B., Schenck, D., Burmester, S., Böttger, M., and Lüthen. H. 2006. How does auxin enhance cell elongation? Role of auxin-binding proteins and potassium channels in growth control. Plant Biology 8(3):346-352. https://doi.org/10.1055/s-2006-923965

Cleland, R. 1971. Cell wall extension. Annual Review of Plant Physiology 22:197-222. https://doi.org/10.1146/annurev.pp.22.060171.001213

Duby, G. and Boutry, M. 2009. The plant plasma membrane proton pump ATPase: a highly regulated P-type ATPase 
with multiple physiological roles. Pflügers Archiv-European Journal of Physiology 457(3):645-655. https:// doi:10.1007/s00424-008-0457-x

Falhof, J., Pedersen, J.T., Fuglsang, A. T., and Palmgren, M. 2016. Plasma membrane $\mathrm{H}^{+}$-ATPase regulation in the center of plant physiology. Molecular Plant 9(3):323-337. https://doi.org/10.1016/j.molp.2015.11.002

Felle, H. 1988. Auxin causes oscillations of cytosolic free calcium and pH in Zea mays coleoptiles. Planta 174(4):495499. https://doi.org/10.1007/BF00634478

Felle, H. H. 2001. pH: Signal and messenger in plant cells. Plant Biology 3(6):577-591. https://doi. org/10.1055/s-2001-19372

Felle, H., Brummer, B., Bertl, A., and Parish, R. W. 1986. Indole3 -acetic acid and fusicoccin cause cytosolic acidification of corn coleoptile cells. Proceedings of the National Academy of Sciences of the USA 83(23):8992-8995. https://doi. org/10.1073/pnas.83.23.8992

Felle, H., Peters, W., and Palme, K. 1991. The electrical response of maize to auxins. Biochimica et Biophysica Acta 1064(2):199-204. https://doi.org/10.1016/00052736(91)90302-O

Fendrych, M., Leung, J., and Friml, J. 2016. TIR1/AFB-Aux/IAA auxin perception mediates rapid cell wall acidification and growth of Arabidopsis hypocotyls. eLife 5:e19048. https://doi.org/10.7554/eLife.19048

Ferl, R. J. 2004. 14-3-3 proteins: regulation of signal-induced events. Physiologia Plantarum 120(2):173-178. https:// doi.org/10.1111/j.0031-9317.2004.0239.x

Fuglsang, A. T., Guo, Y., Cuin, T. A., Qiu, Q., Song, C., Kristiansen, K. A., Bych, K., Schulz, A., Shabala, S., Schumaker, K. S., Palmgren, M. G., and Zhu, J.-K. 2007. Arabidopsis protein kinase PKS5 inhibits the plasma membrane $\mathrm{H}^{+}$-ATPase by preventing interaction with 14-3-3 protein. Plant Cell 19(5):1617-1634. https://doi.org/10.1105/ tpc. 105.035626

Fuglsang, A.T., Tulinius, G., Cui, N., and Palmgren, M. G. 2006. Protein phosphatase $2 \mathrm{~A}$ scaffolding subunit $A$ interacts with plasma membrane $\mathrm{H}^{+}$-ATPase $\mathrm{C}$-terminus in the same region as 14-3-3 protein. Physiologia Plantarum 128(2):334-340. https://doi.org/10.1111/j.13993054.2006.00757.x

Gao, Y., Zhang, Y., Zhang, D., Dai, X., Estelle, M. and Zhao, Y. 2015. Auxin binding protein 1 (ABP1) is not required for either auxin signaling or Arabidopsis development. Proceedings of the National Academy of Sciences of the USA 112(7):2275-2280. https://doi.org/10.1073/ pnas. 1500365112

Gaxiola, R. A., Palmgren, M. G., and Schumacher, K. 2007. Plant proton pumps. FEBS Letters 581(12):2204-2214. https://doi.org/10.1016/j.febslet.2007.03.050

Gehring, C. A., Irving, H., and Parish, R.W. 1990. Effects of auxin and abscisic acid on cytosolic calcium and $\mathrm{pH}$ in plant cells. Proceedings of the National Academy of Sciences of the USA 87(24):9645-9649. https://doi.org/10.1073/ pnas.87.24.9645

Grones, P. and Friml, J. 2015. ABP1: finally docking. Molecular Plant 8(3):356-358. https://doi.org/10.1016/j. molp.2014.12.013

Hagen, G. and Guilfoyle, T. 2002. Auxin-responsive gene expression: genes, promoters and regulatory factors. Plant Molecular Biology 49(3-4):373-385. https://doi. org/10.1023/A:1015207114117

Hager, A., Debus, G., Edel, H. G., Stransky, H., and Serrano, R. 1991. Auxin induces exocytosis and the rapid synthesis of a high-turnover pool of plasma-membrane $\mathrm{H}^{+}$ATPase. Planta 185(4):527-537. https://doi.org/10.1007/ BF00202963
Hager, A., Menzel, H., and Krauss, A. 1971. Experiments and hypothesis concerning the primary action of auxin in elongation growth. Planta 100(1):47-75. https://doi. org/10.1007/BF00386886

Hager, A. and Moser, I. 1985. Acetic acid esters and permeable weak acids induce active proton extrusion and extension growth of coleoptile segments by lowering the cytoplasmic pH. Planta 163(3):391-400. https://doi. org/10.1007/BF00395148

Haruta, M., Burch, H. L., Nelson, R. B., Barrett-Wilt, G., Kline, K. G., Mohsin, S. B., and Sussman, M. R. 2010. Molecular characterization of mutant Arabidopsis plants with reduced plasma membrane proton pump activity. Journal of Biological Chemistry 285(23):17918-17929. https://doi.org/10.1074/jbc.M110.101733

Haruta, M., Gray, W. M., and Sussman, M. R. 2015. Regulation of the plasma membrane proton pump ( $\mathrm{H}^{+}$-ATPase) by phosphorylation. Current Opinion in Plant Biology 28:6875. https://doi.org/10.1016/j.pbi.2015.09.005

Hayashi, M., Inoue, S. I., Takahashi, K., and Kinoshita, T. 2011. Immunohistochemical detection of blue light-induced phosphorylation of the plasma membrane $\mathrm{H}^{+}$-ATPase in stomatal guard cells. Plant and Cell Physiology 52(7):12381248. https://doi.org/10.1093/pcp/pcr072

Hayashi, Y., Takahashi, K., Inoue, S. I., and Kinoshita, T. 2014. Abscisic acid suppresses hypocotyl elongation by dephosphorylating plasma membrane $\mathrm{H}^{+}$-ATPase in Arabidopsis thaliana. Plant and Cell Physiology 55(4):845-853. https://doi.org/10.1093/pcp/pcu028

Hwang, J. U., Gu, Y., Lee, Y. J., and Yang, Z. 2005. Oscillatory ROP GTPase activation leads the oscillatory polarized growth of pollen tubes. Molecular Biology of the Cell 16(11):53855399. https://doi.org/10.1091/mbc.E05-05-0409

Irving, H., Gehring, C. A., and Parish, R. W. 1992. Changes in cytosolic $\mathrm{pH}$ and calcium of guard cells precede stomatal movements. Proceedings of the National Academy of Sciences of the USA 89(5):1790-1794. https://doi. org/10.1073/pnas.89.5.1790

Jones, A. M. and Herman, E. 1993. KDEL-containing auxinbinding protein is secreted to the plasma membrane and cell wall. Plant Physiology 101(2):595-606. https:// doi.org/10.1104/pp.101.2.595

Kasamo, K. 2003. Regulation of plasma membrane $\mathrm{H}^{+}$-ATPase activity by the membrane environment. Journal of Plant Research 116(6):517-523. https://doi.org/10.1007/ s10265-003-0112-8

Kim, Y.-S., Kim, D., and Jung, J. 2000. Two isoforms of soluble auxin receptor in rice (Oryza sativa L.) plants: binding property for auxin and interaction with plasma membrane $\mathrm{H}^{+}$-ATPase. Plant Growth Regulation 32(2-3):143150. https://doi.org/10.1023/A:1010745310101

Kim, Y.-S., Min, J. K., Kim, D., and Jung, J. 2001. A soluble auxinbinding protein, ABP57 purification with anti-bovine serum albumin antibody and characterization of its mechanistic role in the auxin effect on plant plasma membrane $\mathrm{H}^{+}$-ATPase. Journal of Biological Chemistry 276(14):1073010736. https://doi.org/10.1074/jbc.M009416200

Kinoshita, T., and Shimazaki, K.-I. 2001. Analysis of the phosphorylation level in guard-cell plasma membrane $\mathrm{H}^{+}$ATPase in response to fusicoccin. Plant and Cell Physiology 42(4):424-432. https://doi.org/10.1093/pcp/pce055

Kirpichnikova, A. A., Rudashevskaya, E. L., Yemelyanov, V. V., and Shishova, M. F. 2014. Ca ${ }^{2+}$-transport through plasma membrane as a test of auxin sensitivity. Plants 3(2):209222. https://doi.org/10.3390/plants3020209

Klambt D. 1990. A view about the function of auxin-binding proteins at plasma membranes. Plant Molecular Biology 14(6):1045-1050. https://doi.org/10.1007/BF00019401 
Knauss, S., Rohrmeier, T., and Lehle, L. 2003. The auxin-induced maize gene ZmSAUR2 encodes a short-lived nuclear protein expressed in elongating tissues. Journal of Biological Chemistry 278(26):23936-23943. https://doi. org/10.1074/jbc.M212585200

Li, X., Liu, G., Geng, Y., Wu, M., Pei, W., Zhai, H., Zang, X., Li, X., Zhang, J., Yu, Sh., Yu, J. 2017. A genome-wide analysis of the small auxin up RNA (SAUR) gene family in cotton BMC Genomics 18:815-837. https://doi.org/10.1186/s12864017-4224-2

MacDonald, H. 1997. Auxin perception and signal transduction. Physiologia Plantarum 100(3):423-430. https://doi. org/10.1111/j.1399-3054.1997.tb03046.x

Michalko, J., Dravecka, M., Bollenbach, T., and Friml, J. 2015. Embryo-lethal phenotypes in early abp1 mutants are due to disruption of the neighboring BSM gene. F1000Research 4:1104. https://doi.org/10.12688/f1000research.7143.1

Michalko, J., Glanc, M., Perrot-Rechenmann, C., and Friml, J. 2016. Strong morphological defects in conditional Arabidopsis abp1 knock-down mutants generated in absence of functional ABP1 protein. F1000Research 5:86. https:// doi.org/10.12688/f1000research.7654.1

Monshausen, G. B., Miller, N. D., Murphy, A. S., and Gilroy, S. 2011. Dynamics of auxin-dependent $\mathrm{Ca}^{2+}$ and $\mathrm{pH}$ signaling in root growth revealed by integrating highresolution imaging with automated computer visionbased analysis. Plant Journal 65(2):309-318. https://doi. org/10.1111/j.1365-313X. 2010.04423.x

Morales-Cedillo, F., González-Solís, A., Gutiérrez-Angoa, L., Cano-Ramírez, D. L., and Gavilanes-Ruiz, M. 2015. Plant lipid environment and membrane enzymes: the case of the plasma membrane $\mathrm{H}^{+}$-ATPase. Plant Cell Reports 34(4):617629. https://doi.org/10.1007/s00299-014-1735-z

Morandini, P., Valera, M., Albumi, C., Bonza, M. C., Giacometti, S., Ravera, G., and De Michelis, M. I. 2002. A novel interaction partner for the C-terminus of Arabidopsis thaliana plasma membrane $\mathrm{H}^{+}$-ATPase (AHA1 isoform): site and mechanism of action on $\mathrm{H}^{+}$-ATPase activity differ from those of 14-3-3 proteins. Plant Journal 31(4):487497. https://doi.org/10.1046/j.1365-313X.2002.01373.x

Morth, J.P., Pedersen, B.P., Buch-Pedersen, M. J., Andersen, J. P., Vilsen, B., Palmgren, M. G., and Nissen, P. 2011. A structural overview of the plasma membrane $\mathrm{Na}^{+}, \mathrm{K}^{+}$ATPase and $\mathrm{H}^{+}$-ATPase ion pumps. Nature Reviews Molecular Cell Biology 12:60-70. https://doi.org/10.1038/ nrm3031

Murphy, A. S., and Peer, W. A. 2012. Vesicle trafficking: ROPRIC round about. Current Biology 22(14):R576-R578. https://doi.org/10.1016/j.cub.2012.06.008

Nühse, T. S., Bottrill, A. R., Jones, A. M., and Peck, S. C. 2007. Quantitative phosphoproteomic analysis of plasma membrane proteins reveals regulatory mechanisms of plant innate immune responses. Plant Journal 51(5):931940. https://doi.org/10.1111/j.1365-313X.2007.03192.x

Nühse, T.S., Stensballe, A., Jensen, O.N., and Peck, S.C. 2003. Large-scale analysis of in vivo phosphorylated membrane proteins by immobilized metal ion affinity chromatography and mass spectrometry. Molecular and Cellular Proteomics 2(11):1234-1243. https://doi. org/10.1074/mcp.T300006-MCP200

Olsson, A., Svennelid, F., Sommarin B. E. M., and Larsson C. 1998. A phosphothreonine residue at the c-terminal end of the plasma membrane $\mathrm{H}^{+}$-ATPase is protected by fusicoccin-induced 14-3-3 binding. Plant Physiology 118(2):551-555. https://doi.org/10.1104/pp.118.2.551

Palmgren, M. G. 2001. Plant plasma membrane $\mathrm{H}^{+}$-ATPases: powerhouses for nutrient uptake. Annual Review of Plant
Biology 52:817-845. https://doi.org/10.1146/annurev.arplant.52.1.817

Pedersen, B.P., Buch-Pedersen, M.J., Morth, J.P., Palmgren, M. G., and Nissen, P. 2007. Crystal structure of the plasma membrane proton pump. Nature 450(7172):1111-1114. https://doi.org/10.1038/nature06417

Pedersen, C. N., Axelsen, K. B., Harper, J. F., and Palmgren, M. G. 2012. Evolution of plant P-type ATPases. Frontiers in Plant Science 3:31. https://doi.org/10.3389/fpls.2012.00031

Phillips, G. D., Preshaw, C., and Steer, M. W. 1988. Dictyosome vesicle production and plasma membrane turnover in auxin-stimulated outer epidermal cells of coleoptile segments from Avena sativa (L.). Protoplasma 145(1):59-65. https://doi.org/10.1007/BF01323257

Planes, M. D., Niñoles, R., Rubio, L., Bissoli, G., Bueso E., García-Sánchez, M.J., Alejandro, S., Gonzalez-Guzmán, M., Hedrich, R., Rodriguez, P. L., Fernández, J. A., and Serrano R. 2015. A mechanism of growth inhibition by abscisic acid in germinating seeds of Arabidopsis thaliana based on inhibition of plasma membrane $\mathrm{H}^{+}$-ATPase and decreased cytosolic $\mathrm{pH}, \mathrm{K}^{+}$, and anions. Journal of Experimental Botany 66(3):813-825. https://doi.org/10.1093/ jxb/eru442

Polevoi, V. 1986. Rol' auksina v sistemakh regulyatsii u rastenii [Role of Auxin in Regulatory Systems of Plants]. Nauka Publishing, Leningrad.

Polevoi, V. V., Sinyutina, N. F., Salamatova, T. S., Inge-Vechtomova, N. I., Tankelyun, O. V., Sharova, E. I., and Shishova, M.F. 1996. Mechanism of auxin action: second messengers; pp. 223-231 in A. R. Smith, A.W. Berry, N. V.J. Harpham, I. E. Moshkov, G. V. Novikova, O. N. Kulaeva, and M. A. Hall (eds.), Plant hormone signal perception and transduction. Kluwer Academic Publishers, Dordrecht-Boston-London. https://doi.org/10.1007/97894-009-0131-5_30

Polevoi, V. V., and Salamatova T. A. 1977. Auxin, proton pump and cell trophics; pp. 209-216 in E. Marre, O. Ciferri (eds.), Regulation of cell membrane activities in plants. Elsevier, Amsterdam.

Portillo, F. 2000. Regulation of plasma membrane $\mathrm{H}^{+}$-ATPase in fungi and plants. Biochimica et Biophysica Acta (BBA)Reviews on Biomembranes 1469(1):31-42. https://doi. org/10.1016/S0304-4157(99)00011-8

Quaite, E., Parker, R., and Steer, M. 1983. Plant cell extension: Structural implications for the origin of the plasma membrane. Plant, Cell and Environment 6(5):429-432. https://doi.org/10.1111/j.1365-3040.1983.tb01277.x

Ren, H. and Gray, W. M. 2015. SAUR proteins as effectors of hormonal and environmental signals in plant growth. Molecular Plant 8(8):1153-1164. https://doi. org/10.1016/j.molp.2015.05.003

Rubinstein, B. and Stern, A. I. 1986. Relationship of transplasmalemma redox activity to proton and solute transport by roots of Zea mays. Plant Physiology 80(4):805-811. https://doi.org/10.1104/pp.80.4.805

Ruck, A., Palme, K., Venis, M. A., Napier, R. M., and Felle, H. 1993. Patch-clamp analysis establishes a role for an auxin-binding protein in the auxin stimulation of plasma membrane current in Zea mays protoplasts. Plant Journal 4(1):41-46. https://doi.org/10.1046/j.1365313X.1993.04010041.x

Rudashevskaya, E. L., Ye, J., Jensen, O. N., Fuglsang, A. T., and Palmgren, M. G. 2012. Phosphosite mapping of P-type plasma membrane $\mathrm{H}^{+}$-ATPase in homologous and heterologous environments. Journal of Biological Chemistry 287(7):4904-4913. https://doi.org/10.1074/jbc. M111.307264 
Schenck, D., Christian, M., Jones, A., and Lüthen, H. 2010. Rapid auxin-induced cell expansion and gene expression: a four-decade-old question revisited. Plant Physiology 152(3):1183-1185. https://doi.org/10.1104/ pp.109.149591

Shishova, M. and Lindberg, S. 1999. Auxin induces cytosol acidification in wheat leaf protoplasts depends on external concentration of $\mathrm{Ca}^{2+}$. Journal of Plant Physiology 155(2):190-196. https://doi.org/10.1016/S01761617(99)80006-6

Shishova, M. and Lindberg, S. 2004. Auxin induces an increase of $\mathrm{Ca}^{2+}$ concentration in the cytosol of wheat leaf protoplasts. Journal of Plant Physiology 161(8):937-945. https://doi.org/10.1016/j.jplph.2003.12.005

Shishova, M. and Lindberg, S. 2010. A new perspective on auxin perception. Journal of Plant Physiology 167(6):417422. https://doi.org/10.1016/j.jplph.2009.12.014

Shishova, M.F., Inge-Vechtomova, N. I., Vykhvalov, K. A., Rudashevskaya, E. L., and Polevoi, V.V. 1998. Auxin-dependent transport of $\mathrm{K}^{+}$and $\mathrm{Ca}^{2+}$ across the membrane of plasmalemma vesicles from coleoptile cells. Russian Journal of Plant Physiology 45(1):67-73.

Shishova, M. F., Lindberg, S. M., and Polevoi, V. V. 1999. Auxin activation of $\mathrm{Ca}^{2+}$ transport across the plasmalemma of plant cells. Russian Journal of Plant Physiology 46(5):626633.

Shishova, M. F., Rudashevskaya, E. L., Inge-Vechtomova, N. I., Glinkina, M. V., Kirpichnikova, A. A., and Vykhvalov, K. A. 1999. Svoystva kationnykh kanalov plazmalemmy kletok koleoptiley kukuruzy, aktiviruemykh auksinom [Quality of maize coleoptile cell plasma membrane cation channels operated by auxin]. Biological Communications [s.l.] (3):36-43

Shishova, M., Yemelyanov, V., Rudashevskaya, E., and Lindberg, S. 2007. A shift in sensitivity to auxin within development of maize seedlings. Journal of Plant Physiology 164(10):1323-1330. https://doi.org/10.1016/j. jplph.2006.09.005

Spartz, A. K., Lee, S. H., Wenger, J.P., Gonzalez, N., Itoh, H., Inzé, D., and Gray, W. M. 2012. The SAUR19 subfamily of SMALL AUXIN UP RNA genes promote cell expansion. Plant Journal 70(6):978-990. https://doi.org/10.1111/ j.1365-313X.2012.04946.X

Spartz, A. K., Ren, H., Park, M.Y., Grandt, K. N., Lee, S. H., Murphy, A.S., Sussman, M.R., Overvoorde, P.J., and Gray, W. M. 2014. SAUR inhibition of $\mathrm{PP}_{2} \mathrm{C}-\mathrm{D}$ phosphatas- es activates plasma membrane $\mathrm{H}^{+}$-ATPases to promote cell expansion in Arabidopsis. Plant Cell 26(5):2129-2142. https://doi.org/10.1105/tpc.114.126037

Sutter, J., Homann, U., and Thiel, G. 2000. Ca ${ }^{2+}$-stimulated exocytosis in maize coleoptile cells. Plant Cell 12(7):11271136. https://doi.org/10.1105/tpc.12.7.1127

Takahama, U., and Oniki, T. 1994. The association of ascorbate and ascorbate oxidase in the apoplast with IAAenhanced elongation of epicotyls from Vigna angularis. Plant and Cell Physiology 35(2):257-266. https://doi. org/10.1093/oxfordjournals.pcp.a078591

Takahashi, K., Hayashi, K., and Kinoshita, T. 2012. Auxin activates the plasma membrane $\mathrm{H}^{+}$-ATPase by phosphorylation during hypocotyl elongation in Arabidopsis. Plant Physiology 159(2):632-641. https://doi.org/10.1104/ pp.112.196428

Tian, H., Dieter, K. D., and Jones A. 1995. Auxin-binding protein 1 does not bind auxin within the endoplasmic reticulum despite this being the predominant subcellular location for this hormone receptor. Journal of Biological Chemistry 270(45):26962-26969. https://doi.org/10.1074/ jbc.270.45.26962

Ueno, K., Kinoshita, T., Inoue, S., Emi, T., and Shimazaki, K. 2005. Biochemical characterization of plasma membrane $\mathrm{H}^{+}$-ATPase activation in guard cell protoplasts of Arabidopsis thaliana in response to blue light. Plant and Cell Physiology 46(6):955-963. https://doi.org/10.1093/ pcp/pci104

Vanneste, S., and Friml, J. 2013. Calcium: The missing link in auxin action. Plants 2(4):650-675. https://doi. org/10.3390/plants2040650

Viotti, C., Luoni, L., Morandini, P., and De Michelis, M. I. 2005. Characterization of the interaction between the plasma membrane $\mathrm{H}^{+}$-ATPase of Arabidopsis thaliana and a novel interactor (PPI1). FEBS Journal 272(22):5864-5871. https://doi.org/10.1111/j.1742-4658.2005.04985.x

Xu, T., When, M., Nagawa, S., Fu, Y., Chen, J.-G., Wu, M.-J., Perrot-Rechenmann, K., Friml, J., Jones, A., and Yang, Z. 2011. Cell surface- and Rho GTPase-based auxin signaling controls cellular interdigitation in Arabidopsis. Cell 143(1):99110. https://doi.org/10.1016/j.cell.2010.09.003

Yalovsky, S., Bloch, D., Sorek, N., and Kost, B. 2008. Regulation of membrane trafficking, cytoskeleton dynamics, and cell polarity by ROP/RAC GTPases. Plant Physiology 147(4):1527-1543. https://doi.org/10.1104/ pp.108.122150 